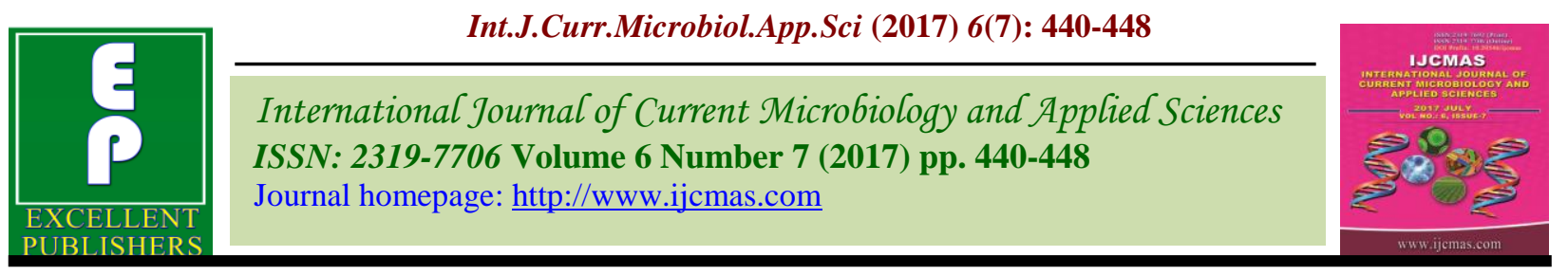

Original Research Article https://doi.org/10.20546/ijcmas.2017.607.053

\title{
Influence of Postharvest Treatments on Quality of Loose Flowers of Polianthes tuberosa Linn. cv. Prajwal
}

\author{
Subhra Shil ${ }^{1}$, Suhrita Chakrabarty ${ }^{2}$ and Venkata Satish Kuchi ${ }^{3 *}$ \\ ${ }^{1}$ Divyodaya Krishi Vigyan Kendra, Cebri, Khowai, Tripura 799207, India \\ ${ }^{2}$ Department of Postharvest Technology, Faculty of Horticulture, BCKV, Nadia, \\ West Bengal 741252, India \\ ${ }^{3}$ Department of Postharvest Technology, College of Horticulture, Dr. YSRHU, Anantharajupeta, \\ Andhra Pradesh 516105, India \\ *Corresponding author
}

A B S T R A C T

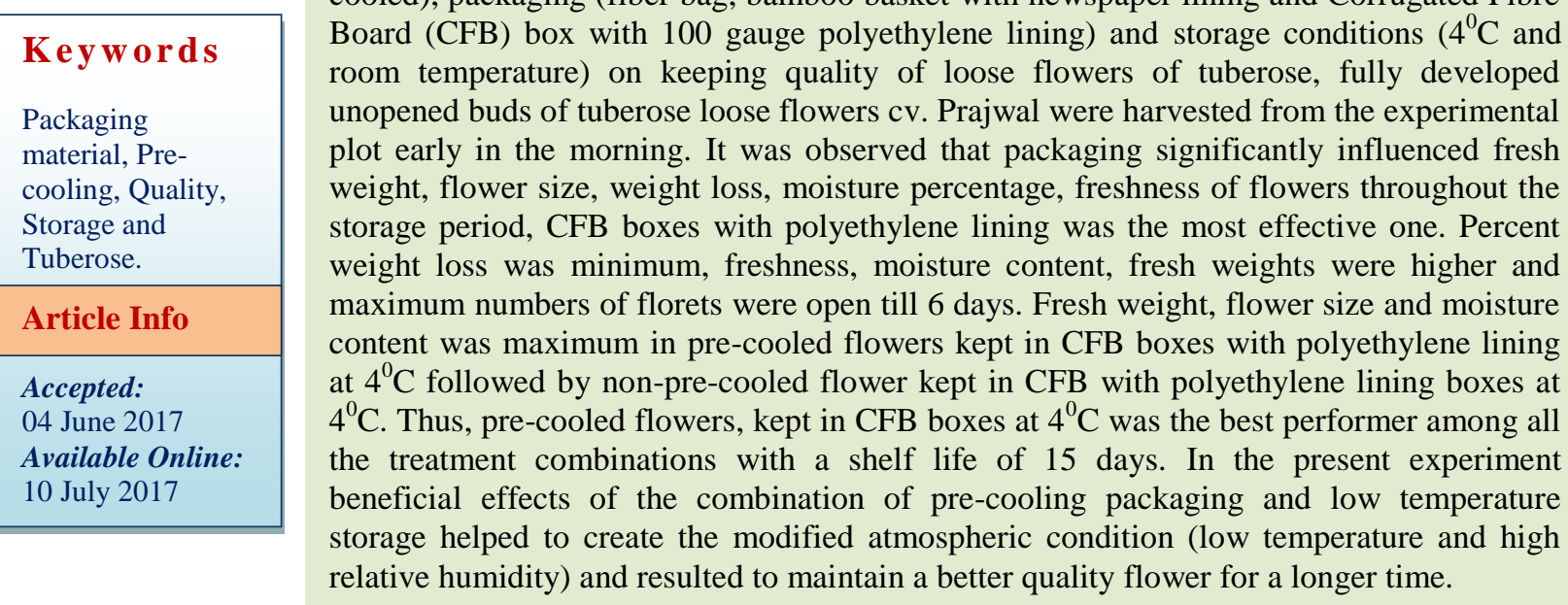

\section{Introduction}

Flowers are the most beautiful creation of the earth. Flowers symbolize beauty, purity, peace, love affection and honesty. Flowers have been associated with Indian art and culture from the time immemorial starting with the offering of flowers during worship by the ancient Rishis (sages). The estimated area under flower crops in India is about 191 thousand hectares (2010-11) and production of cut and loose flower is about 69027 lakh in numbers and 1031 thousand metric tonnes, respectively. The total area under floriculture in West Bengal is 23.1 thousand hactare, on which loose flower production is 59.2 thousand metric tonnes and cut flowers produced are about 23919 lakh in numbers (Anonymous, 1987). West Bengal shares highest area under cut flower production in India and shares around $34.65 \%$ of total production. 
Among the cut flowers produced, tuberose (Polianthes tuberosa Linn.), a member of family Amarayllidaceae, native to Mexico is one of the most important bulbous perennial crop grown in many tropical subtropical parts of the world and occupies a very selective and special position because of its beauty, elegance and sweet pleasant fragrance. Tuberose is also known as Glushaboo (Hindi); Rajanigandha (Bengali); Sukandaraji, Nelasapenji (Telegu); Nilasampanji (Tamil); Sugandharaja, Nelasamping or Sandharaga (Kanarese). Tuberose is commercially cultivated for cut and loose flower trade, and also it has long been cherished for aromatic oil extracted from its fragrant white flowers (Trueblood, 1973). Assam, Maharashtra, Gujarat, Haryana, Karnataka, Andhra Pradesh, Tamil Nadu, Uttar Pradesh, Uttrakhanda and Orissa are the major states where tuberose has become very popular. It is estimated that in India tuberose is commercially cultivated over 30,000 hactare area (Singh et al., 2010).

The survey made by International Trade Center UNCTAD/GATT, Geneva indicated that tuberose as a cut flower has tremendous demand in Belgium, France, and U.K (Anon, 1987). To meet this demand, tuberose is commercially cultivated in China, Egypt, France, Israel, Italy, New Zealand, South Africa, Spain, Sri Lanka, United States of America and In India, where, it is cultivated in large scale in the states of West Bengal, Karnataka, Tamilnadu, Andhra Pradesh, Maharashtra, Orissa, Gujarat, Uttar Pradesh, Haryana, Delhi. Tuberose usually needs to be transported from the production region to the remote market with a market price of 5 to 10 Rs. per spike (Tripati, 2012). It is estimated that there is about $20 \%$ loss of tuberose occur during market. Due to their extreme perishable nature proper treatment is required to maintain the quality of tuberose (Hardenburg, 1990). However, lack of knowledge regarding proper post-harvest handling is one of the limiting factors in expansion of the trade and export of tuberose.

Modified atmosphere packaging of fresh commodities is a successful technology for prolonging the post-harvest life during storage and marketing (Kader, 1986). One of the major benefits of modified atmosphere packaging (MAP) is the prevention or retardation of flower senescence and associated with physiological and biochemical changes (Sandhya, 2010).

Dry storage of flowers also helps in prolonging the duration of transport. Dry storage of flowers involves keeping the flowers in package boxes and stored at room temperature or under controlled conditions by maintaining temperature, relative humidity and air circulation without keeping them in water or any other preservative solutions. The main problem of dry storage is moisture loss or desiccation. To minimize this water loss wrapping material of different types are used. This technology was used in our present investigation and the main objective of the present study was to find out best wrapping material for enhancing the vase-life of tuberose cut flowers cv. Calcutta Double. For loose flower production, tuberose is harvested at fully opened stage (Bhattacharjee, 2001).But it has been found that these are also harvested at fully developed bud stage. Tuberose loose florets are used for various decoration purposes and also for extraction of essential oil. Picking of individual flowers which grow at the horizontal position on the flower stalk is done early in the morning. Harvesting those in the previous evening, and marketing in the next day, leads to the weight loss of about 40 percent (Rameshwar, 1976). However, there are few reports on the studies of extension of loose tuberose flowers with the help of different packaging materials (Nagaraja et al., 1999a; Nagaraja et al., 
1999b). Thus, the present investigation aimed to find out best packaging material for enhancing shelf life of tuberose loose flowers under West Bengal condition so that the flowers can be available to the end users (consumers, oil extractors, decorators making floral ornaments and likewise) for longer duration. Therefore, keeping in mind, the above discussed factors regarding the tuberose flowers (Cut and loose, both), present investigation "Influence of postharvest treatments on quality of loose flowers of Polianthes tuberosa linn. cv. Prajwal" was planned.

\section{Materials and Methods}

The experiment was conducted in the laboratory of the Department of Post-Harvest Technology Horticultural Crops, Faculty of Horticulture, Bidhan Chandra Krishi Viswavidyalaya, Mohanpur, Nadia, West Bengal, during 2011-2012. The experimental details and techniques employed in the study are described as follows:

\section{Site of experiment}

Tuberose crop were grown in an experimental plot of Mondouri, Horticultural research station, Nadia, West Bengal. The post-harvest experiments were conducted under laboratory conditions at the Department of Post-Harvest Technology of Horticultural Crops, Faculty of Horticulture, Bidhan Chandra Krishi Viswavidyalaya Mohanpur; Nadia; West Bengal during 2011-2012.

For the experiment cut tuberose of $\mathrm{cv}$. Calcutta Double and loose tuberose of cv. Prajwal were collected from an experimental plot of Mondouri, Horticultural research station, Nadia, West Bengal. The experimental plot were well prepared by repeated tilling and application of organic manure $\left(@ 5 \mathrm{~kg} / \mathrm{m}^{2}\right)$ and inorganic fertilizer (N: P: K@ 100: 100: 150).

\section{Packaging materials}

In order to study the effect of packaging and storage on keeping quality of loose flowers of tuberose, fully developed unopened buds of tuberose loose flower cv. Prajwal was harvested from the experimental plot early in the morning.

The harvested buds were divided into two lots viz. pre-cooled (PC) and non-pre-cooled (NPC) each containing $1200 \mathrm{~g}$ of loose flower. One lot was kept for pre-cooling at $4^{\circ} \mathrm{C}$ and second lot was kept in ambient temperature for 24 hours.

After 24hrs the lots were equally divided into two halves and loose florets were then packed in different packing material i.e. fiber bag, round bamboo basket with newspaper lining and CFB box with 100 gauge polyethylene lining (200g in each packaging material) and stored at $4^{\circ} \mathrm{C}$ and ambient temperature. This was also followed in non-pre-cooled (NPC) lots.

\section{Laboratory condition}

The temperature measured in Celsius scale and relative humidity, measured by hygrometer inside the laboratory during the experiments. Average light intensity inside the laboratory was 250 lux. Vase water used for experiment was normal distilled water.

\section{Variety}

Prajwal (This cultivar bears single type flowers on tall, stiff spikes. The flower buds are slightly pinkish in colour while the open flowers are white. The individual florets are heavier in weight and larger in size compared to Mexican single. It yields $20 \%$ more loose flowers than Shringar. This cultivar is best suited for loose flower, cut flower and perfumery industry). 
Fully developed unopened buds were harvested from the field. The flowers were subjected to treatments pre-cooling at $4^{0} \mathrm{C}$ (PC) and non-pre-cooling (NPC). Then, they were packed in three packages i.e., Fiber bag (34 cm x $21 \mathrm{~cm})$, Round Bamboo basket with newspaper lining and CFB box $(20 \mathrm{~cm} \times 12 \mathrm{~cm}$ $\mathrm{x} 7 \mathrm{~cm}$ ) with 100 gauge polyethylene lining. Later, they were stored in ambient condition and at $4^{0} \mathrm{C}$. Each treatment was replicated thrice. The sample size is $200 \mathrm{~g} /$ replication.

\section{Observations recorded}

Fresh weight of flowers was measured using a weighing balance and diameter of the flower was determined using Vernier calipers. Physiological loss in weight (PLW \%) and moisture content (\%) were computed by the methods suggested by Ranganna (1999). Freshness percentage was calculated using the below formula

$$
\text { Freshness } \%=\frac{\text { Number of fresh florets }}{\text { Total number of florets }}
$$

\section{Statistical analysis}

Factorial Completely Randomized Design (CRD) method was used for calculating the variance of the experiment (Gomez and Gomez, 1984).

\section{Results and Discussion}

Freshness of tube rose floret was significantly influenced by pre-cooling $\left(4^{\circ} \mathrm{C}\right)$, packaging material (fiber bag, gunny bag, CFB box with polyethylene lining) and storage temperature $\left(4^{0} \mathrm{C}\right)$. Maximum freshness was retained in pre cooled flower stored in corrugated fiber box (CFB) box with polyethylene lining at low temp $\left(4^{0} \mathrm{C}\right)$ followed by non pre cooled flowers stored in CFB box with polyethylene lining at low temperature. Pre cooled flower stored in CFB box with polyethylene lining at low temperature maintained $100 \%$ freshness till $9^{\text {th }}$ day and retained $64.67 \%$ on $15^{\text {th }}$ day of storage. Minimum freshness of $75.57 \%$ on $6^{\text {th }}$ day and $22.79 \%$ on $9^{\text {th }}$ day was observed in non pre cooled flowers stored in bamboo basket under room temperature (Table 1).

Data presented in table 2 revealed that flower size generally increased during the initial phase of storage, varying from treatment to treatment, and gradually decreased at the later part of storage period. Individual effect of packaging materials, storage temperature and their interaction significantly influenced the flower size on $6^{\text {th }}$ day onward. However, precooling significantly improved flower size on $9^{\text {th }}$ day and $12^{\text {th }}$ days only. The maximum flower size $(3 \mathrm{~cm})$ was obtained in loose flowers pre cooled at $4^{\circ} \mathrm{C}$ and stored in CFB box at low temp $\left(4^{\circ} \mathrm{C}\right)$. Whereas, non pre cooled flower stored in bamboo basket with newspaper lining at room temperature exhibited least flower size of $0.53 \mathrm{~cm}$ on $6^{\text {th }}$ day of storage.

The weight loss of loose florets was significantly influenced by individual effect of pre-cooling, packaging and storage temperature and also with their interaction effects on $6^{\text {th }}$ days onward (Table 3 ). Florets kept in CFB box with polyethylene lining at low temperature without pre cooling initially exhibited least weight loss up to 9 days $(0.62 \%, 1.33 \%, 2.28 \%$ at $3,6,9$ days respectively), followed by pre cooled flower kept in CFB box with polyethylene lining under low temperature $\left(4^{\circ} \mathrm{C}\right)$ which showed weight loss up to $0.67 \%, 1.6 \%, 3.08 \%$ at $3^{\text {rd }} \cdot 6^{\text {th }}$ and $9^{\text {th }}$ of storage, respectively. However, during later part of storage, precooled flower kept in CFB box with polyethylene lining at low temperature resulted in least weight loss, exhibiting weight loss of $2.85 \%$ and $5.85 \%$ on $12^{\text {th }}$ and $15^{\text {th }}$ days of storage, respectively. 
Data presented in table 4 revealed that highest moisture content was maintained initially in non-pre-cooled flower kept in CFB box with polyethylene lining under low temperature $\left(99.42 ; 98.67 ; 97.2 \%\right.$ on $3^{\text {rd }}$, 6th and $9^{\text {th }}$ day respectively).

Whereas during the later part, pre-cooled flower kept in CFB box with polyethylene lining under low temperature could retained the moisture to highest extend $97.15 \%$ on $12^{\text {th }}$ day, $94.10 \%$ on $15^{\text {th }}$ day.

The least moisture content was observed in non pre cooled flower stored in bamboo basket under ambient situation $\left(87.58 \%\right.$ on $3^{\text {rd }}$ day) where, pre cooled flower stored in bamboo basket under ambient situation exhibited least moisture $\left(69.40 \%\right.$ on $6^{\text {th }}$ day). It was observed from the data presented in table 5 that loose florets of tuberose $\mathrm{cv}$. Prajwal could be stored up to 15 days at $4^{\circ} \mathrm{C}$ in CFB box with polyethylene lining when pre cooled at $4^{\circ} \mathrm{C}$, resulting to maximum fresh weight $188.30 \mathrm{~g}$.

On the other hand, florets kept in bamboo basket without pre-cooling under ambient condition exhibited least freshness on $3^{\text {rd }}$ day $(175.17 \mathrm{~g})$ and $6^{\text {th }}$ day $(138.10 \mathrm{~g})$. These florets could not be stored beyond 6 days.

Pre-cooling of tuberose florets at $4^{\circ} \mathrm{C}$ followed by packaging in $\mathrm{CFB}$ box with polyethylene lining with vent and subsequent storage at low temperature condition $\left(4^{\circ} \mathrm{C}\right)$ significantly improved the shelf life, weight loss, moisture per cent and freshness throughout the storage period 15 days.

Table.1 Effect of pre-cooling, packaging and storage on shelf life and Freshness of loose flowers of tuberose cv. Prajwal

\begin{tabular}{|c|c|c|c|c|c|}
\hline \multirow{2}{*}{ Treatment } & \multirow{2}{*}{ Shelf life } & \multicolumn{4}{|c|}{ Freshness at } \\
\hline & & 6 days & 9 days & 12 days & 15 days \\
\hline \multicolumn{6}{|l|}{$\mathbf{C} \square \mathbf{P} \square \mathbf{T}$} \\
\hline $\mathrm{C}_{1} \mathrm{P}_{1} \mathrm{~T}_{1}$ & 10.00 & 100.00 & 90.40 & 44.40 & 0.00 \\
\hline $\mathrm{C}_{1} \mathrm{P}_{1} \mathrm{~T}_{2}$ & 8.00 & 85.87 & 55.47 & 0.00 & 0.00 \\
\hline $\mathrm{C}_{1} \mathrm{P}_{2} \mathrm{~T}_{1}$ & 6.00 & 100.00 & 53.63 & 0.00 & 0.00 \\
\hline $\mathrm{C}_{1} \mathrm{P}_{2} \mathrm{~T}_{2}$ & 6.00 & 77.60 & 32.97 & 0.00 & 0.00 \\
\hline $\mathrm{C}_{1} \mathrm{P}_{3} \mathrm{~T}_{1}$ & 17.00 & 100.00 & 100.00 & 96.80 & 64.67 \\
\hline $\mathrm{C}_{1} \mathrm{P}_{3} \mathrm{~T}_{2}$ & 9.00 & 100.00 & 56.90 & 33.73 & 0.00 \\
\hline $\mathrm{C}_{2} \mathrm{P}_{1} \mathrm{~T}_{1}$ & 10.00 & 100.00 & 87.50 & 39.87 & 0.00 \\
\hline $\mathrm{C}_{2} \mathrm{P}_{1} \mathrm{~T}_{2}$ & 8.00 & 84.30 & 52.87 & 0.00 & 0.00 \\
\hline $\mathrm{C}_{2} \mathrm{P}_{2} \mathrm{~T}_{1}$ & 6.00 & 99.00 & 50.33 & 0.00 & 0.00 \\
\hline $\mathrm{C}_{2} \mathrm{P}_{2} \mathrm{~T}_{2}$ & 6.00 & 75.57 & 22.79 & 0.00 & 0.00 \\
\hline $\mathrm{C}_{2} \mathrm{P}_{3} \mathrm{~T}_{1}$ & 15.00 & 100.00 & 99.20 & 85.27 & 50.77 \\
\hline $\mathrm{C}_{2} \mathrm{P}_{3} \mathrm{~T}_{2}$ & 8.00 & 100.00 & 40.70 & 0.00 & 0.00 \\
\hline $\operatorname{SEm}( \pm)$ & 0.569 & 0.444 & 3.059 & 0.368 & 0.411 \\
\hline $\mathrm{CD}(\mathrm{P}=0.05)$ & NS & NS & NS & 1.079 & 1.205 \\
\hline
\end{tabular}

$\mathrm{C}_{1}=$ pre- cooled, $\mathrm{C}_{2}=$ non pre- cooled, $\mathrm{P}_{1}=$ fiber bag, $\mathrm{P}_{2}=$ bamboo basket, $\mathrm{P}_{3}=\mathrm{CFB}, \mathrm{T}_{1}=4^{0} \mathrm{C}, \mathrm{T}_{2}=$ room temperature, 
Table.2 Effect of pre-cooling, packaging and storage on flower size $(\mathrm{cm})$ of Loose flowers of tuberose cv. Prajwal

\begin{tabular}{|c|c|c|c|c|c|}
\hline \multirow{2}{*}{ Treatment } & \multicolumn{5}{|c|}{ Flower size(cm) at } \\
\cline { 2 - 6 } & $\mathbf{3}$ days & $\mathbf{6}$ days & $\mathbf{9}$ days & $\mathbf{1 2}$ days & $\mathbf{1 5}$ days \\
\hline $\mathbf{C} \square \mathbf{P} \square \mathbf{T}$ & & & & & \\
\hline $\mathrm{C}_{1} \mathrm{P}_{1} \mathrm{~T}_{1}$ & 1.97 & 2.13 & 1.03 & 0.00 & 0.00 \\
\hline $\mathrm{C}_{1} \mathrm{P}_{1} \mathrm{~T}_{2}$ & 2.17 & 1.43 & 0.00 & 0.00 & 0.00 \\
\hline $\mathrm{C}_{1} \mathrm{P}_{2} \mathrm{~T}_{1}$ & 2.40 & 0.67 & 0.00 & 0.00 & 0.00 \\
\hline $\mathrm{C}_{1} \mathrm{P}_{2} \mathrm{~T}_{2}$ & 1.53 & 0.67 & 0.00 & 0.00 & 0.00 \\
\hline $\mathrm{C}_{1} \mathrm{P}_{3} \mathrm{~T}_{1}$ & 2.00 & 2.40 & 3.00 & 2.37 & 1.13 \\
\hline $\mathrm{C}_{1} \mathrm{P}_{3} \mathrm{~T}_{2}$ & 2.00 & 2.77 & 0.97 & 0.00 & 0.00 \\
\hline $\mathrm{C}_{2} \mathrm{P}_{1} \mathrm{~T}_{1}$ & 1.73 & 2.27 & 1.00 & 0.00 & 0.00 \\
\hline $\mathrm{C}_{2} \mathrm{P}_{1} \mathrm{~T}_{2}$ & 1.93 & 0.67 & 0.00 & 0.00 & 0.00 \\
\hline $\mathrm{C}_{2} \mathrm{P}_{2} \mathrm{~T}_{1}$ & 2.07 & 0.73 & 0.00 & 0.00 & 0.00 \\
\hline $\mathrm{C}_{2} \mathrm{P}_{2} \mathrm{~T}_{2}$ & 1.80 & 0.53 & 0.00 & 0.00 & 0.00 \\
\hline $\mathrm{C}_{2} \mathrm{P}_{3} \mathrm{~T}_{1}$ & 1.83 & 2.70 & 2.37 & 1.83 & 1.30 \\
\hline $\mathrm{C}_{2} \mathrm{P}_{3} \mathrm{~T}_{2}$ & 2.63 & 2.33 & 0.00 & 0.00 & 0.00 \\
\hline $\mathbf{S E m} \mathbf{(})$ & $\mathbf{0 . 2 3 8}$ & $\mathbf{0 . 1 3 7}$ & $\mathbf{0 . 0 8 0}$ & $\mathbf{0 . 0 3 5}$ & $\mathbf{0 . 0 4 6}$ \\
\hline $\mathbf{C D}(\mathbf{P}=\mathbf{0 . 0 5})$ & $\mathbf{N S}$ & $\mathbf{N S}$ & $\mathbf{N S}$ & $\mathbf{0 . 1 0 3}$ & $\mathbf{N S}$ \\
\hline
\end{tabular}

$\mathrm{C}_{1}=$ pre- cooled, $\mathrm{C}_{2}=$ non pre- cooled, $\mathrm{P}_{1}=$ fiber bag, $\mathrm{P}_{2}=$ bamboo basket, $\mathrm{P}_{3}=\mathrm{CFB}, \mathrm{T}_{1}=4^{0} \mathrm{C}, \mathrm{T}_{2}=$ room temperature,

Table.3 Effect of pre-cooling, packaging and storage on weight loss (\%) of Loose flowers of tuberose cv. Prajwal

\begin{tabular}{|c|c|c|c|c|c|}
\hline \multirow{2}{*}{ Treatment } & \multicolumn{5}{|c|}{ Weight loss at } \\
\cline { 2 - 6 } & 3 days & 6 days & 9 days & 12 days & 15 days \\
\hline $\mathbf{C} \square \mathbf{P} \square \mathbf{T}$ & & & & & \\
\hline $\mathrm{C}_{1} \mathrm{P}_{1} \mathrm{~T}_{1}$ & 6.48 & 15.47 & 23.53 & 0.00 & 0.00 \\
\hline $\mathrm{C}_{1} \mathrm{P}_{1} \mathrm{~T}_{2}$ & 7.62 & 19.92 & 0.00 & 0.00 & 0.00 \\
\hline $\mathrm{C}_{1} \mathrm{P}_{2} \mathrm{~T}_{1}$ & 10.32 & 26.72 & 0.00 & 0.00 & 0.00 \\
\hline $\mathrm{C}_{1} \mathrm{P}_{2} \mathrm{~T}_{2}$ & 10.57 & 30.60 & 0.00 & 0.00 & 0.00 \\
\hline $\mathrm{C}_{1} \mathrm{P}_{3} \mathrm{~T}_{1}$ & 0.67 & 1.60 & 3.08 & 2.85 & 5.85 \\
\hline $\mathrm{C}_{1} \mathrm{P}_{3} \mathrm{~T}_{2}$ & 1.94 & 4.50 & 6.25 & 0.00 & 0.00 \\
\hline $\mathrm{C}_{2} \mathrm{P}_{1} \mathrm{~T}_{1}$ & 6.48 & 16.30 & 23.98 & 32.23 & 0.00 \\
\hline $\mathrm{C}_{2} \mathrm{P}_{1} \mathrm{~T}_{2}$ & 8.12 & 21.77 & 0.00 & 0.00 & 0.00 \\
\hline $\mathrm{C}_{2} \mathrm{P}_{2} \mathrm{~T}_{1}$ & 10.55 & 27.90 & 40.92 & 0.00 & 0.00 \\
\hline $\mathrm{C}_{2} \mathrm{P}_{2} \mathrm{~T}_{2}$ & 12.43 & 29.37 & 0.00 & 0.00 & 0.00 \\
\hline $\mathrm{C}_{2} \mathrm{P}_{3} \mathrm{~T}_{1}$ & 0.62 & 1.33 & 2.28 & 5.28 & 9.78 \\
\hline $\mathrm{C}_{2} \mathrm{P}_{3} \mathrm{~T}_{2}$ & 2.19 & 4.95 & 0.00 & 0.00 & 0.00 \\
\hline $\mathbf{S E m} \mathbf{m} \mathbf{m}$ & $\mathbf{0 . 3 1 7}$ & $\mathbf{0 . 3 8 9}$ & $\mathbf{0 . 3 6 8}$ & $\mathbf{0 . 4 9 3}$ & $\mathbf{0 . 5 6 9}$ \\
\hline $\mathbf{C D}(\mathbf{P}=\mathbf{0 . 0 5})$ & $\mathbf{N S}$ & $\mathbf{1 . 1 4 1}$ & $\mathbf{1 . 0 7 9}$ & $\mathbf{1 . 4 4 6}$ & $\mathbf{1 . 6 6 9}$ \\
\hline
\end{tabular}

$\mathrm{C}_{1}=$ pre- cooled, $\mathrm{C}_{2}=$ non pre- cooled, $\mathrm{P}_{1}=$ fiber bag, $\mathrm{P}_{2}=$ bamboo basket, $\mathrm{P}_{3}=\mathrm{CFB}, \mathrm{T}_{1}=4^{0} \mathrm{C}, \mathrm{T}_{2}=$ room temperature, 
Table.4 Effect of pre-cooling, packaging and storage on moisture per cent of Loose flowers of tuberose cv. Prajwal

\begin{tabular}{|c|c|c|c|c|c|}
\hline \multirow{2}{*}{ Treatment } & \multicolumn{5}{|c|}{ Moisture per cent at } \\
\cline { 2 - 6 } $\mathbf{C} \square \mathbf{P} \square \mathbf{T}$ & & $\mathbf{6}$ days & & $\mathbf{1 2}$ days & $\mathbf{1 5}$ days \\
\hline $\mathrm{C}_{1} \mathrm{P}_{1} \mathrm{~T}_{1}$ & 93.53 & 84.53 & 76.47 & 0.00 & 0.00 \\
\hline $\mathrm{C}_{1} \mathrm{P}_{1} \mathrm{~T}_{2}$ & 92.38 & 80.08 & 0.00 & 0.00 & 0.00 \\
\hline $\mathrm{C}_{1} \mathrm{P}_{2} \mathrm{~T}_{1}$ & 89.68 & 73.28 & 0.00 & 0.00 & 0.00 \\
\hline $\mathrm{C}_{1} \mathrm{P}_{2} \mathrm{~T}_{2}$ & 89.45 & 69.40 & 0.00 & 0.00 & 0.00 \\
\hline $\mathrm{C}_{1} \mathrm{P}_{3} \mathrm{~T}_{1}$ & 99.33 & 98.40 & 96.92 & 97.15 & 94.15 \\
\hline $\mathrm{C}_{1} \mathrm{P}_{3} \mathrm{~T}_{2}$ & 98.10 & 95.50 & 93.75 & 0.00 & 0.00 \\
\hline $\mathrm{C}_{2} \mathrm{P}_{1} \mathrm{~T}_{1}$ & 93.52 & 83.70 & 76.02 & 67.77 & 0.00 \\
\hline $\mathrm{C}_{2} \mathrm{P}_{1} \mathrm{~T}_{2}$ & 91.88 & 78.23 & 0.00 & 0.00 & 0.00 \\
\hline $\mathrm{C}_{2} \mathrm{P}_{2} \mathrm{~T}_{1}$ & 89.45 & 72.10 & 59.08 & 0.00 & 0.00 \\
\hline $\mathrm{C}_{2} \mathrm{P}_{2} \mathrm{~T}_{2}$ & 87.58 & 70.63 & 0.00 & 0.00 & 0.00 \\
\hline $\mathrm{C}_{2} \mathrm{P}_{3} \mathrm{~T}_{1}$ & 99.42 & 98.67 & 97.72 & 94.72 & 90.22 \\
\hline $\mathrm{C}_{2} \mathrm{P}_{3} \mathrm{~T}_{2}$ & 97.82 & 95.05 & 0.00 & 0.00 & 0.00 \\
\hline $\mathbf{S E m} \mathbf{( \pm )}$ & $\mathbf{0 . 3 1 4}$ & $\mathbf{0 . 3 8 9}$ & $\mathbf{0 . 3 6 8}$ & $\mathbf{0 . 4 9 3}$ & $\mathbf{0 . 5 6 9}$ \\
\hline $\mathbf{C D}(\mathbf{P}=\mathbf{0 . 0 5})$ & $\mathbf{N S}$ & $\mathbf{1 . 1 4 1}$ & $\mathbf{1 . 0 7 9}$ & $\mathbf{1 . 4 4 6}$ & $\mathbf{1 . 6 6 9}$ \\
\hline
\end{tabular}

$\mathrm{C}_{1}=$ pre- cooled, $\mathrm{C}_{2}=$ non pre- cooled, $\mathrm{P}_{1}=$ fiber bag, $\mathrm{P}_{2}=$ bamboo basket, $\mathrm{P}_{3}=\mathrm{CFB}, \mathrm{T}_{1}=4^{0} \mathrm{C}, \mathrm{T}_{2}=$ room temperature,

Table.5 Effect of pre-cooling, packaging and storage on fresh weight of Loose flowers of tuberose cv. Prajwal

\begin{tabular}{|c|c|c|c|c|c|}
\hline \multirow{2}{*}{ Treatment } & \multicolumn{5}{|c|}{ Fresh weight at } \\
\hline & 3 days & 6 days & 9 days & 12 days & 15 days \\
\hline \multicolumn{6}{|l|}{$\mathbf{C} \times \mathbf{P} \times \mathbf{T}$} \\
\hline $\mathrm{C}_{1} \mathrm{P}_{1} \mathrm{~T}_{1}$ & 187.07 & 169.07 & 152.93 & 0.00 & 0.00 \\
\hline $\mathrm{C}_{1} \mathrm{P}_{1} \mathrm{~T}_{2}$ & 184.77 & 160.17 & 0.00 & 0.00 & 0.00 \\
\hline $\mathrm{C}_{1} \mathrm{P}_{2} \mathrm{~T}_{1}$ & 179.37 & 146.57 & 116.30 & 0.00 & 0.00 \\
\hline $\mathrm{C}_{1} \mathrm{P}_{2} \mathrm{~T}_{2}$ & 178.90 & 138.80 & 0.00 & 0.00 & 0.00 \\
\hline $\mathrm{C}_{1} \mathrm{P}_{3} \mathrm{~T}_{1}$ & 198.67 & 196.80 & 193.83 & 194.30 & 188.30 \\
\hline $\mathrm{C}_{1} \mathrm{P}_{3} \mathrm{~T}_{2}$ & 196.20 & 191.00 & 187.50 & 0.00 & 0.00 \\
\hline $\mathrm{C}_{2} \mathrm{P}_{1} \mathrm{~T}_{1}$ & 187.03 & 167.40 & 152.03 & 0.00 & 0.00 \\
\hline $\mathrm{C}_{2} \mathrm{P}_{1} \mathrm{~T}_{2}$ & 183.77 & 156.47 & 0.00 & 0.00 & 0.00 \\
\hline $\mathrm{C}_{2} \mathrm{P}_{2} \mathrm{~T}_{1}$ & 178.90 & 144.20 & 0.00 & 0.00 & 0.00 \\
\hline $\mathrm{C}_{2} \mathrm{P}_{2} \mathrm{~T}_{2}$ & 175.17 & 141.27 & 0.00 & 0.00 & 0.00 \\
\hline $\mathrm{C}_{2} \mathrm{P}_{3} \mathrm{~T}_{1}$ & 198.83 & 197.33 & 195.43 & 189.43 & 180.43 \\
\hline $\mathrm{C}_{2} \mathrm{P}_{3} \mathrm{~T}_{2}$ & 195.63 & 190.10 & 0.00 & 0.00 & 0.00 \\
\hline SEm ( \pm$)$ & 0.629 & 0.779 & 0.687 & 0.965 & 1.138 \\
\hline $\mathrm{CD}(\mathrm{P}=0.05)$ & NS & 2.285 & 2.015 & NS & 3.338 \\
\hline
\end{tabular}

$\mathrm{C}_{1}=$ pre- cooled, $\mathrm{C}_{2}=$ non pre- cooled, $\mathrm{P}_{1}=$ fiber bag, $\mathrm{P}_{2}=$ bamboo basket, $\mathrm{P}_{3}=\mathrm{CFB}, \mathrm{T}_{1}=4^{0} \mathrm{C}, \mathrm{T}_{2}=$ room temperature 
This finding accorded with those reported earlier for tuberose (Madaiah and Reddy, 1994; Madaiah and Reddy, 1992; Nagaraja et al., 1999a; Nagaraja et al., 1999b) and jasmine (Nirmala and Reddy, 1992; Thamaraiselvi et al., 2011).

Pre-cooling of tuberose florets essentially helped to remove field heat from flower which ultimately resulted into increase in shelf life. Pre-cooling was a very important step in proper storage management whenever flowers were held dry packed. Pre-cooling reduced field heat and respiration, prevented moisture from condensing on the flowers, reduced the risk of infection and reduced the amount of ethylene inside the package.

The florets in CEB boxes with PE lining had less physiological loss in weight (PLW) with increased freshness as because the said packaging material could retain higher moisture content leading to delay in the appearance of wilting symptoms (Madaiah and Reddy, 1992). This was probably due to the modified atmosphere condition of gaseous composition and high relative humidity created by the CFB boxes with PE lining (Anzeuto and Rizvi, 1985).

Further, storage of tuberose after pre-cooling and packaging, under low temperature condition helped to increase the shelf life significantly. Due to maintenance of lower temperature along with high humidity (in the CFB box with polyethylene lining) the rate of moisture loss from the flower was reduced in the present investigation, leading to reduction in physiological loss in weight (PLW) and maintenance of freshness. The rate of respiration and other enzymatic activities were also probably much lower, there by delaying the senescence process in the florets. These findings accorded with those of other researchers (Madaiah and Reddy, 1992) who reported extension of storage life of flowers by using lower temperature. According to Reid (1992), reduction the metabolism in, however, was only one of the benefits of lowering the temperature of harvesting ornamentals. Besides, metabolism and the senescence process underlain, the post-harvest life of harvested ornamentals was also affected by loss of water, loss of respirable substrate, attack by micro-organisms and undesirable growth and development.

In the present experiment beneficial effects of the combination of pre-cooling packaging and low temperature storage helped to create the modified atmospheric condition (low temperature and high relative humidity) and resulted to maintain a better quality flower for a longer time.

\section{References}

Anonymous. 1987. Floricultural products. A study of major markets. International Trade Center, UNCTDA/GATT, Geneva. pp. 1-10.

Anzueto, C.R. and Rizvi, S.S.H. 1985. Individual packaging of apples for shelf life extension. Journal of Food Science. 50(4): 897-900.

Bhattacharjee, S.K. 2001. Post-harvest management of flowers. In: Hand book of Horticulture. Chadh,K.L. (Ed). New Delhi, India: Indian Council of Agricultural Research. pp. 969-981.

Gomez, K.A. and Gomez, A.A. 1984. Statistical procedures for agricultural research, ( $2^{\text {nd }}$ edn.) John Wiley and Sons, New York.

Hardenburg, R.E. 1990. The commercial storage of fruits, vegetables, and florist and nursery stocks. USDA Agriculture Handbook pp 66.

Kader, A.A. 1986. Modified atmosphere packaging (MAP) for long-term shipment of cut flowers. Acta Hortculturea. 553: 631-634. 
Madaiah, D. and Reddy, T.V. 1992. Influence of polyethylene packaging and cool chamber storage on the post- harvest life of tuberose (cv. Single) florets. Karnataka Journal of Agricultural science.

Madaiah, D. and Reddy, T.V. 1994. Influence of polyethylene packaging on the postharvest life of tuberose (cv. Single) florets. Karnataka Journal of Agricultural Science. 7(2): 154-157.

Nagaraja, G.S., Gowda, J.V.N. and Farooqi, A.A. 1999a. Influence of chemicals and packaging on the shelf life of tuberose flowers. Karnataka Journal of Agricultural Sciences. 12(1/4): 132-136.

Nagaraja, G.S., Gowda, J.V.N. and Farooqi, A.A. 1999b. Shelf life of tuberose flowers as influenced by packaging and ventilation. Karnataka Journal of Agricultural Sciences. 12(1/4): 239-242.

Nirmala, S. and Reddy, T.V. 1993. Extension of shelf life of Jasminum multiflorum through packaging. Journal of Maharashtra Agricultural University 27: 272-276

Rameshwar, A. 1976. Tuberose cultivation around Bangalore. Indian Horticulture. 21:22-23.
Ranganna, S. 1999. Handbook of Analysis and Quality Control for Fruit and vegetable Products. $2^{\text {nd }}$ Edition. Tata and McGraw - Hill Publishig Co. Ltd., New Delhi. pp. 98-99.

Reid, M. S. 1992. Post-harvest technology of horticultural crops. $2^{\text {nd }}$ Edition. Ed. A. A. Kader. UCDANR Pub 3311, pp 201209.

Sandhya. 2010. Effect of Pre- and Postharvest treatment on flower longevity of tuberose. Acta Horiculturea. 482: 83-87.

Singh, P.K., Kadam, G.B. and Jyoti, R. 2010. Production Manual on Tuberose (Polianthes tuberose L.) pp.1-2.

Thamaraiselvi, S.P., Jawaharlal, M., Rajamani, K. and Ganga, M. 2011. Studies on packaging technology for long term storage of Jasminum grandiflorum L. flowers. Advances in Plant Sciences. 24(1): 223-230.

Tripati, A. (2010). Independent market survey (2010-11). Kurushetra, A journal on rural development. 60: 42-43.

Trueblood, E.W.E. 1973. The tuberose (Polianthes tuberose L.) Economic Botany. pp.27:157.

\section{How to cite this article:}

Subhra Shil, Suhrita Chakrabarty and Venkata Satish Kuchi. 2017. Influence of Postharvest Treatments on Quality of Loose Flowers of Polianthes tuberosa Linn. cv. Prajwal. Int.J.Curr.Microbiol.App.Sci. 6(7): 440-448. doi: https://doi.org/10.20546/ijcmas.2017.607.053 